\title{
Assessment of Heavy Metal Pollution of Dustfall in Xi'an City, Northwest China
}

\author{
Ying Chen", Jianqiang Zhao, Wenjuan Yang and Bo Hu \\ School of Environmental Science and Engineering, Chang'an University, Xi'an 710054, China \\ Key Laboratory of Subsurface Hydrology and Ecological Effect in Arid Region of Ministry of Education, Xi'an 710054, China \\ *Corresponding author
}

\begin{abstract}
Air pollution caused by Atmospheric Particulate Matter (APM) and its impacts have become one of the most important challenges for public health and environmental quality in China since 2000s. Here we report a study of heavy metal pollution in atmospheric deposition in $\mathrm{Xi}^{\mathrm{i}}$ 'an city. Dustfall samples were wet collected by the gravimetric method at four sampling stations located in different functional districts of city month by month in 2014. The concentration of heavy metal such as $\mathrm{Pb}, \mathrm{Zn}, \mathrm{Cu}, \mathrm{Cr}$, Ni and $\mathrm{Cd}$ was analyzed with ICP-MS and the atmospheric heavy metals deposition were calculated simultaneously. The results indicated that the annual average dustfall flux in industrial district, commercial district, cultural and educational district and scenic zone was $17.84 \mathrm{t} /\left(\mathrm{km}^{2} \cdot 30 \mathrm{~d}\right)$, $15.99 \mathrm{t} /\left(\mathrm{km}^{2} \cdot 30 \mathrm{~d}\right), 15.46 \mathrm{t} /\left(\mathrm{km}^{2} \cdot 30 \mathrm{~d}\right)$ and $11.76 \mathrm{t} /\left(\mathrm{km}^{2} \cdot 30 \mathrm{~d}\right)$, much higher than the limits of foreign related standards, which showed that the dustfall pollution in Xi'an city was serious. Furthermore, the annual average concentration of $\mathrm{Pb}, \mathrm{Zn}, \mathrm{Cu}, \mathrm{Cr}, \mathrm{Ni}, \mathrm{Cd}$ bounded with dustfall was $438.1 \mathrm{mg} / \mathrm{kg}, 454.9 \mathrm{mg} / \mathrm{kg}, 61.1 \mathrm{mg} / \mathrm{kg}$, $149.5 \mathrm{mg} / \mathrm{kg}, 41.4 \mathrm{mg} / \mathrm{kg}$ and $7.8 \mathrm{mg} / \mathrm{kg}$ respectively, which was 20.5, 6.6, 2.9, 2.4, 1.4 and 83.0 times of the soil background value in Shaanxi province. Pollution of $\mathrm{Pb}, \mathrm{Cr}$ and $\mathrm{Cd}$ was serious and enriched distinctly. The calculated atmospheric heavy metal deposition of $\mathrm{Pb}, \mathrm{Zn}, \mathrm{Cu}, \mathrm{Cr}, \mathrm{Ni}$ and $\mathrm{Cd}$ was $81.35 \mathrm{mg} /\left(\mathrm{m}^{2} \cdot \mathrm{a}\right)$, $84.47 \mathrm{mg} /\left(\mathrm{m}^{2} \cdot \mathrm{a}\right), 11.35 \mathrm{mg} /\left(\mathrm{m}^{2} \cdot \mathrm{a}\right), 27.76 \mathrm{mg} /\left(\mathrm{m}^{2} \cdot \mathrm{a}\right), 7.69 \mathrm{mg} /\left(\mathrm{m}^{2} \cdot \mathrm{a}\right)$ and $1.45 \mathrm{mg} /\left(\mathrm{m}^{2} \cdot \mathrm{a}\right)$ respectively.
\end{abstract}

Keywords-dustfall; atmospheric deposition; heavy metal; pollution; Xi'an city

\section{INTRODUCTION}

Air pollution caused by Atmospheric Particulate Matter(APM) and its impacts have become one of the most important challenges for public health and environmental quality in China since $2000 \mathrm{~s}^{[1]}$. Xi' an city is one of the most seriously affected areas by APM as its special geographical location, rapid economic growth and increase in industrial activity. APM typically comprises a complex mixture of different elements and compounds with heavy metal content particularly significant due to its toxicity and harmful effects on health ${ }^{[2]}$. Dustfall, a kind of APM usually with grain size $>$ $10 \mu \mathrm{m}$, can be settled on ground naturally by gravity in common air condition. Sometimes some smaller particles with grain size $<10 \mu \mathrm{m}$ can also be settled down to the ground in specific weather conditions such as static wind, high air humidity and precipitation. The pollution level of dustfall not only has significant indicative sense to the ambient air quality, but also contributes to runoff and soil pollution increasingly.
Here we report a study of heavy metal pollution in atmospheric deposition in Xi'an city. Dustfall samples were wet collected by the gravimetric method at four control points of national ambient air quality located in industrial district, commercial district, cultural and educational district and scenic zone month by month in 2014. The concentration of heavy metal such as $\mathrm{Pb}, \mathrm{Zn}, \mathrm{Cu}, \mathrm{Cr}$, Ni and $\mathrm{Cd}$ was tested with ICP-MS and the atmospheric heavy metals deposition flux was calculated simultaneously.

\section{MATERIALS AND METHODS}

\section{A. Sampling Sites}

4 sampling sites were set up at control points of national ambient air quality located in different functional regions in Xi'an. The detail of the sampling sites was shown in Table 1.

TABLE I. SAMPLING SITES OF ATMOSPHERIC DUSTFALL

\begin{tabular}{|c|c|c|}
\hline No & Geographical Coordinates & Representative Functional District \\
\hline 1 & $\begin{array}{c}\text { east longitude } 108^{\circ} 52^{\prime} 56.0^{\prime \prime} \\
\text { north latitude } 34^{\circ} 16^{\prime} 29.7^{\prime \prime}\end{array}$ & industrial district \\
\hline 2 & $\begin{array}{c}\text { east longitude } 108^{\circ} 52^{\prime} 59.2^{\prime \prime} \\
\text { north latitude } 34^{\circ} 13^{\prime} 49.1^{\prime \prime}\end{array}$ & commercial district \\
\hline 3 & $\begin{array}{c}\text { east longitude } 108^{\circ} 56^{\prime} 27.1^{\prime \prime} \\
\text { north latitude } 34^{\circ} 13^{\prime} 20.3^{\prime \prime}\end{array}$ & cultural and educational district \\
\hline 4 & $\begin{array}{c}\text { east longitude } 108^{\circ} 59^{\prime} 05.2^{\prime \prime} \\
\text { north latitude } 34^{\circ} 11^{\prime} 52.1^{\prime \prime}\end{array}$ & scenic district \\
\hline
\end{tabular}

\section{B. $\quad$ Sampling Method}

Tailor-made tripod was set in the middle of the sampling platform at the 4 control points of national ambient air quality located in different urban functional district. The dustfall samples were collected month by month in 2014 by using the collecting gauges (150 $\mathrm{mm}$ in diameter, $300 \mathrm{~mm}$ in depth) which were fixed on the tripods with $1.5 \mathrm{~m}$ above the ground at each site to avoid being turned over by wind of small particles being removed into the collecting gauges by wind. During the study period, 48 dustfall samples were gotten.

\section{Measuring Method of Dustfall Flux}

Dustfall flux of every month in 4 sampling sites was measured with reference to national recommended Gravimetric Method. 


\section{Measuring Method of Heavy Metal Concentration}

All samples were air-dried and sieved through a $1 \mathrm{~mm}$ mesh to remove obvious refuses. Samples collected in March to May of each sampling site were blended representing spring dustfall of the sampling site. Samples collected in June to August of each sampling site were blended representing summer dustfall. Samples collected in September to November of each sampling site were blended representing autumn dustfall. Samples collected in January, February and December of each sampling site were blended representing winter dustfall. 16 dustfall samples representing 4 seasons of 4 sampling sites were prepared to analyze the heavy metal concentration in the Key Laboratory of Subsurface Hydrology and Ecological Effect in Arid Region of Ministry of Education. The method used for heavy metal analysis is described by Yang ${ }^{[3]}$ and $\mathrm{Qiao}^{[4]}$. The extraction of heavy metals $(\mathrm{Pb}, \mathrm{Zn}, \mathrm{Cu}, \mathrm{Cr}, \mathrm{Cd}$ and $\mathrm{Ni}$ ) in dustfall samples was carried out in sealed resolution tank of $100 \mathrm{~mL}$ made by PTFE by digesting about $0.15 \mathrm{~g}$ accurately weighted of the samples with $5 \mathrm{~mL}$ concentrated $\mathrm{HNO}_{3}, 2 \mathrm{~mL}$ $\mathrm{H}_{2} \mathrm{O}_{2}$ and $2 \mathrm{~mL} \mathrm{HF}$. All the chemical reagents are guaranteed reagents. The mixture was heated at $160^{\circ} \mathrm{C}$ for 9 hours in a drying oven, then removed to the fume hood to cool to the room temperature and then catched acid. Then the mixture was transferred in $25 \mathrm{~mL}$ colorimetric cylinder with $0.5 \% \mathrm{HNO}_{3}$, then filtered on $0.45 \mu \mathrm{m}$ filter membrane and transferred to 10 $\mathrm{mL}$ centrifuge tube for analyzing. The concentration of $\mathrm{Pb}, \mathrm{Zn}$, $\mathrm{Cu}, \mathrm{Cr}, \mathrm{Cd}$ and $\mathrm{Ni}$ in dustfall was analyzed by inductively-coupled plasma-mass spectrometry (ICP-MS) method. To assess the accuracy of the results obtained by the methods used in this study, blank solutions were also prepared in the same manner as that employed for the dust samples. No contamination with heavy metals was found in the blank solutions that were checked. Furthermore, one sample selected randomly was analyzed repeatedly and the relative standard deviations of the 6 elements were less then $10 \%$ uniformly.

\section{E. Calculating Method of Atmospheric Heavy Metal Deposion Flux}

Atmospheric heavy metal deposition was calculated based on the dustfall flux and concentration of heavy metals derived from the study. The calculation equation is shown in (1).

$$
A P_{j}=D F_{a a} \times C_{a j}
$$

Where $A P_{j}$ is the atmospheric deposition of heavy metal $j$, $D F_{a a}$ is the annual average dustfall flux of 4 seasons from 4 functional districts, $C_{a j}$ is the annual heavy metal concentration of heavy metal $j$ of 4 seasons from 4 functional districts.

\section{RESULTS AND DISCUSSIONS}

\section{A. Dustfall Flux and it's Pollution Level of Xi'an City}

The tested dustfall flux in Xi'an City was shown in Table 2, as well as the statistical properties. It's obvious that dustfall flux in Xi'an city varied widely with time and space. The monthly dustfall flux ranged from $7.89 \sim 24.05 \mathrm{t} /\left(\mathrm{km}^{2} \cdot 30 \mathrm{~d}\right)$ in industry district, $6.05 \sim 22.50 \mathrm{t} /\left(\mathrm{km}^{2} \cdot 30 \mathrm{~d}\right)$ in commercial district, $5.91 \sim 23.16 \mathrm{t} /\left(\mathrm{km}^{2} \cdot 30 \mathrm{~d}\right)$ in cultural and educational district, as well as $3.57 \sim 16.50 \mathrm{t} /\left(\mathrm{km}^{2} \cdot 30 \mathrm{~d}\right)$ in scenic district.
The annual dustfall flux of the 4 functional districts were 17.84 $\mathrm{t} /\left(\mathrm{km}^{2} \cdot 30 \mathrm{~d}\right), 15.99 \mathrm{t} /\left(\mathrm{km}^{2} \cdot 30 \mathrm{~d}\right), 15.46 \mathrm{t} /\left(\mathrm{km}^{2} \cdot 30 \mathrm{~d}\right)$ and $11.76 \mathrm{t} /\left(\mathrm{km}^{2} \cdot 30 \mathrm{~d}\right)$ respectively, the highest one in industry district and the smallest one in scenic zone. The variation coefficients were $0.29,0.31,0.33$ and 0.31 orderly.

TABLE II. DUSTFALL FLUX IN XI’AN CITY

\begin{tabular}{|c|c|c|c|c|}
\hline \multirow{2}{*}{$\begin{array}{c}\text { Sampling } \\
\text { time }\end{array}$} & \multicolumn{4}{|c|}{ Dustfall flux $\left.\left(\mathbf{t} / \mathbf{k m}^{2} \cdot \mathbf{3 0 d}\right)\right)$} \\
\cline { 2 - 5 } & $\begin{array}{c}\text { Industry } \\
\text { district }\end{array}$ & $\begin{array}{c}\text { Commercial } \\
\text { district }\end{array}$ & $\begin{array}{c}\text { Cultural and } \\
\text { education district }\end{array}$ & $\begin{array}{c}\text { Scenic } \\
\text { district }\end{array}$ \\
\hline Jan. & 21.26 & 19.39 & 20.75 & 15.55 \\
\hline Feb. & 22.68 & 19.82 & 18.69 & 14.38 \\
\hline Mar. & 21.32 & 20.18 & 19.01 & 14.06 \\
\hline Apr. & 20.84 & 17.80 & 17.45 & 13.66 \\
\hline May & 21.90 & 20.18 & 18.87 & 11.96 \\
\hline Jun. & 15.30 & 13.01 & 12.20 & 10.58 \\
\hline Jul. & 16.14 & 14.73 & 12.87 & 9.47 \\
\hline Aug & 14.40 & 13.58 & 13.10 & 10.99 \\
\hline Sep. & 7.89 & 6.05 & 5.91 & 3.57 \\
\hline Oct. & 10.56 & 9.29 & 8.83 & 7.46 \\
\hline Nov. & 17.69 & 15.35 & 14.63 & 12.91 \\
\hline Dec. & 24.05 & 22.50 & 23.16 & 16.50 \\
\hline mean & 17.84 & 15.99 & 15.46 & 11.76 \\
\hline median & 19.27 & 16.58 & 16.04 & 12.44 \\
\hline $\begin{array}{c}\text { standard } \\
\text { deviation }\end{array}$ & 5.09 & 4.93 & 5.09 & 3.65 \\
\hline $\begin{array}{c}\text { variation } \\
\text { coefficient }\end{array}$ & 0.29 & 0.31 & 0.33 & 0.31 \\
\hline
\end{tabular}

Although the dusrfall flux is one of the routine monitoring items of ambient air quality, there is no national standard issued about dustfall flux limits in China as the wide-range variation of the actual flux due to the diversity of nature and economy in different regions. Some related standards of dustfall flux limits promulgated by foreign governments were shown in Table 3, as well as the flux values in Xi'an city for comparison. It's obvious that the pollution of dustfall in Xi'an city was serious. The annual average dustfall flux in Xi'an city exceeded those foreign limits greatly, even in the cleanest scenic district. The annual average dustfall flux of scenic district in Xi'an was 2 times above the standard limits of USA and Canada, while the value of most seriously polluted district, industry district, was 3 times above the standard limits. It's evident that the harmful effect of dustfall on environment and human health can not be ignored in Xi'an city.

TABLE III. COMPARISON WITH FOREIGN RELATED STANDARD

\begin{tabular}{|c|c|c|c|}
\hline \multicolumn{2}{|c|}{ Nation or region } & Unit & $\begin{array}{c}\text { Standard limits or } \\
\text { monitoring } \\
\text { values }\left(\mathrm{mg} /\left(\mathrm{m}^{2} \cdot \mathrm{d}\right)\right)\end{array}$ \\
\hline \multicolumn{2}{|c|}{ Kentucky of USA $^{[5]}$} & annual average & 196 \\
\hline \multicolumn{2}{|c|}{ Alberta of Canada $^{[5]}$} & annual average & 180 \\
\hline \multicolumn{2}{|r|}{ Spain $^{[5]}$} & annual average & 200 \\
\hline \multicolumn{2}{|r|}{ Finland $^{[5]}$} & annual average & 333 \\
\hline \multicolumn{2}{|r|}{ Argentina $^{[5]}$} & annual average & 333 \\
\hline \multirow{5}{*}{$\begin{array}{l}\text { Xi'an } \\
\text { City (this } \\
\text { study) }\end{array}$} & industry district & annual average & 594.7 \\
\hline & commercial district & annual average & 533.0 \\
\hline & $\begin{array}{c}\text { cultural and } \\
\text { educational district }\end{array}$ & annual average & 515.3 \\
\hline & scenic district & annual average & 392.0 \\
\hline & mean & annual average & 508.75 \\
\hline
\end{tabular}


B. Heavy Metal Pollution Level of Atmospheric Deposition in Xi'an City

The concentrations of $\mathrm{Pb}, \mathrm{Zn}, \mathrm{Cu}, \mathrm{Cr}, \mathrm{Cd}$ and $\mathrm{Ni}$ of dustfall in 4 sampling sites of 4 seasons were analyzed by ICP-MS and the results were shown in Table 4. It's obvious that the concentration of proposed heavy metals of dustfall in Xi'an City varied widely with seasons and functional zones. The concentrations of $\mathrm{Pb}, \mathrm{Zn}, \mathrm{Cu}, \mathrm{Cr}$, Ni and $\mathrm{Cd}$ of 16 samples ranged from $230.3 \sim 704.7 \mathrm{mg} / \mathrm{kg}, \quad 287.3 \sim 660.2 \mathrm{mg} / \mathrm{kg}$, $32.7 \sim 137.8 \mathrm{mg} / \mathrm{kg}, 60.5 \sim 242.6 \mathrm{mg} / \mathrm{kg}, 18.9 \sim 82.7 \mathrm{mg} / \mathrm{kg}$ and $1.6 \sim 15.7 \mathrm{mg} / \mathrm{kg}$ respectively, and the annual average concentration was $438.1 \mathrm{mg} / \mathrm{kg}, 454.9 \mathrm{mg} / \mathrm{kg}, 61.1 \mathrm{mg} / \mathrm{kg}$, $149.5 \mathrm{mg} / \mathrm{kg}, \quad 41.4 \mathrm{mg} / \mathrm{kg}$ and $7.8 \mathrm{mg} / \mathrm{kg}$ orderly. The descending order of variation of heavy metal concentration was $\mathrm{Cd}>\mathrm{Ni}>\mathrm{Cu}>\mathrm{Cr}>\mathrm{Pb}>\mathrm{Zn}$.

TABLE IV. HEAVY METAL CONCENTRATIONS OF DUST FALL IN XI'AN CITY

\begin{tabular}{|c|c|c|c|c|c|c|c|}
\hline \multirow{2}{*}{$\begin{array}{c}\text { Seaso } \\
\mathbf{n}\end{array}$} & \multirow{2}{*}{ Site No } & \multicolumn{6}{|c|}{ Concentration of heavy metals $(\mathrm{mg} / \mathrm{kg})$} \\
\hline & & $P b$ & $Z n$ & $C u$ & $\mathrm{Cr}$ & $\mathrm{Ni}$ & $C d$ \\
\hline \multirow{4}{*}{ spring } & 1 & 625.0 & 610.6 & 137.8 & 108.8 & 41.2 & 9.3 \\
\hline & 2 & 376.2 & 327.9 & 91.2 & 124.0 & 36.6 & 5.8 \\
\hline & 3 & 476.5 & 552.5 & 47.8 & 113.7 & 65.5 & 9.7 \\
\hline & 4 & 267.9 & 422.0 & 48.3 & 107.8 & 34.5 & 8.8 \\
\hline \multirow{4}{*}{$\begin{array}{c}\text { summ } \\
\text { er }\end{array}$} & 1 & 429.1 & 414.6 & 51.5 & 155.8 & 40.0 & 4.7 \\
\hline & 2 & 426.8 & 287.3 & 47.4 & 150.3 & 33.9 & 4.0 \\
\hline & 3 & 435.1 & 371.8 & 46.4 & 131.2 & 34.9 & 3.7 \\
\hline & 4 & 373.8 & 413.6 & 40.1 & 87.6 & 31.0 & 4.0 \\
\hline \multirow{4}{*}{$\begin{array}{c}\text { autum } \\
\mathrm{e}\end{array}$} & 1 & 354.3 & 428.3 & 39.6 & 106.6 & 20.5 & 8.6 \\
\hline & 2 & 300.5 & 660.2 & 37.9 & 176.9 & 21.7 & 1.6 \\
\hline & 3 & 230.3 & 553.2 & 34.3 & 117.6 & 18.9 & 4.5 \\
\hline & 4 & 510.7 & 393.5 & 32.7 & 60.5 & 19.5 & 2.7 \\
\hline \multirow{4}{*}{ winter } & 1 & 704.7 & 466.4 & 77.8 & 242.6 & 62.2 & 14.2 \\
\hline & 2 & 550.7 & 414.6 & 73.2 & 234.8 & 57.9 & 15.7 \\
\hline & 3 & 532.6 & 459.6 & 91.9 & 237.7 & 82.7 & 14.4 \\
\hline & 4 & 414.6 & 502.5 & 79.7 & 235.9 & 61.3 & 13.4 \\
\hline \multicolumn{2}{|c|}{ mean } & 438.1 & 454.9 & 61.1 & 149.5 & 41.4 & 7.8 \\
\hline \multicolumn{2}{|c|}{ median } & 428.0 & 425.2 & 48.1 & 127.6 & 35.8 & 7.2 \\
\hline \multicolumn{2}{|c|}{$\begin{array}{l}\text { standard } \\
\text { deviation }\end{array}$} & 126.8 & 99.9 & 28.6 & 59.0 & 19.1 & 4.6 \\
\hline \multicolumn{2}{|c|}{$\begin{array}{l}\text { variation } \\
\text { coefficient }\end{array}$} & 0.29 & 0.22 & 0.47 & 0.39 & 0.46 & 0.59 \\
\hline
\end{tabular}

The heavy metal concentrations of dustfall in other cities were shown in Table 5 for comparing with the results of this study. It's obvious that the pollution of $\mathrm{Pb}, \mathrm{Cr}$, and $\mathrm{Cd}$ of dustfall in Xi'an city was very serious and the pollution level was rather high, while the pollution of $\mathrm{Zn}, \mathrm{Cu}$, and $\mathrm{Ni}$ was relatively light. The annual average concentration of $\mathrm{Pb}$, $\mathrm{Zn}, \mathrm{Cu}, \mathrm{Cr}, \mathrm{Ni}$, Cd bounded with dustfall was 20.5, 6.6, 2.9, 2.4, 1.4 and 83.0 times of the soil background value in Shaanxi province. It's evident that those 5 heavy metals except $\mathrm{Ni}$, which mainly originated from soil, were enriched significantly in dustfall because of anthropogenic activities such as industrial production, communication and transportation, building construction and human's civil life. The $\mathrm{Cr}$ and $\mathrm{Cd}$, cancer risk heavy metals, were enriched 2.4 and 83.0 times in dustfall and the harmful effect on environment and human health can not be ignored.

TABLE V. COMPARISON WITH OTHER RELATED STUDIES

\begin{tabular}{|c|c|c|c|c|c|c|}
\hline \multirow{2}{*}{ City } & \multicolumn{6}{|c|}{ Heavy metal concentration in dustfall( $\mathrm{mg} / \mathrm{kg})$} \\
\hline & $P b$ & $Z n$ & $\mathrm{Cu}$ & $\mathrm{Cr}$ & $\mathrm{Ni}$ & $C d$ \\
\hline this study & 438.1 & 454.9 & 61.1 & 149.5 & 41.4 & 7.8 \\
\hline Nanjing ${ }^{[6]}$ & 331 & 798 & 121 & 95.8 & 51.7 & 5.8 \\
\hline Hangzhou $^{[7]}$ & 335 & 1658 & 119 & 26 & 24 & I \\
\hline Quanzhou $^{[8]}$ & 284.49 & 1628.7 & 112.4 & 126.87 & 106.45 & 2.01 \\
\hline Pingdingshan $^{[9]}$ & 331.3 & 534.6 & 97.6 & 142.5 & 52.8 & 3.7 \\
\hline Nantong ${ }^{[10]}$ & 640 & 1417 & 216 & 123 & 46.9 & 4.39 \\
\hline Yixing ${ }^{[10]}$ & 917 & 575 & 86.3 & 138 & 35.6 & 1.62 \\
\hline $\begin{array}{l}\text { soil background } \\
\text { value in } \\
\text { Shaanxi } \\
\text { province }^{[11]}\end{array}$ & 21.4 & 69.4 & 21.4 & 62.5 & 28.8 & 0.094 \\
\hline
\end{tabular}

\section{Atmospheric Heavy Metal Deposion in Xi'an City}

The Calculated atmospheric heavy metal depositions were shown in table 6. It's evident that the heavy metal pollution caused by dustfall was serious in Xi'an and the annual importations of $\mathrm{Pb}, \mathrm{Zn}, \mathrm{Cu}, \mathrm{Cr}$, $\mathrm{Ni}$ and $\mathrm{Cd}$ of atmospheric deposition were $81.35 \mathrm{mg} /\left(\mathrm{m}^{2} \cdot \mathrm{a}\right), 84.47 \mathrm{mg} /\left(\mathrm{m}^{2} \cdot \mathrm{a}\right), 11.35$ $\mathrm{mg} /\left(\mathrm{m}^{2} \cdot \mathrm{a}\right), 27.76 \mathrm{mg} /\left(\mathrm{m}^{2} \cdot \mathrm{a}\right), 7.69 \mathrm{mg} /\left(\mathrm{m}^{2} \cdot \mathrm{a}\right)$ and 1.45 $\mathrm{mg} /\left(\mathrm{m}^{2} \cdot \mathrm{a}\right)$ respectively.

TABLE VI. ATMOSPHERIC HEAVY METAL DEPOSITIONS IN XI'AN CITY

\begin{tabular}{|c|c|c|c|}
\hline $\begin{array}{c}\text { Annual average } \\
\text { dustfall flux } \\
\left(\mathrm{mg} /\left(\mathrm{m}^{2} \cdot \mathrm{d}\right)\right)\end{array}$ & $\begin{array}{c}\text { Heavy } \\
\text { metal }\end{array}$ & $\begin{array}{c}\text { Concentration of } \\
\text { heavy metals } \\
(\mathbf{m g} / \mathbf{k g})\end{array}$ & $\begin{array}{c}\text { Atmospheric } \\
\text { heavy metal } \\
\text { deposition } \\
\left(\mathrm{mg} /\left(\mathrm{m}^{2} \cdot \mathrm{a}\right)\right)\end{array}$ \\
\hline \multirow{6}{*}{508.75} & $\mathrm{~Pb}$ & 438.1 & 81.35 \\
\hline & $\mathrm{Zn}$ & 454.9 & 84.47 \\
\hline & $\mathrm{Cu}$ & 61.1 & 11.35 \\
\hline & $\mathrm{Cr}$ & 149.5 & 27.76 \\
\hline & $\mathrm{Ni}$ & 41.4 & 7.69 \\
\hline & $\mathrm{Cd}$ & 7.8 & 1.45 \\
\hline
\end{tabular}

\section{CONCLUSIONS}

(1) The monthly dustfall flux in Xi'an city ranged from 7.89 24.05 $\mathrm{t} /\left(\mathrm{km}^{2} \cdot 30 \mathrm{~d}\right)$ in industry district, $6.05 \sim 22.50$ $\mathrm{t} /\left(\mathrm{km}^{2} \cdot 30 \mathrm{~d}\right)$ in commercial district, 5.91 23.16 t/(km² $\left.\cdot 30 \mathrm{~d}\right)$ in cultural and educational district, as well as $3.57 \sim 16.50$ $\mathrm{t} /\left(\mathrm{km}^{2} \cdot 30 \mathrm{~d}\right)$ in scenic district. The annual average dustfall flux of the 4 functional districts were $17.84 \mathrm{t} /\left(\mathrm{km}^{2} \cdot 30 \mathrm{~d}\right)$, $15.99 \mathrm{t} /\left(\mathrm{km}^{2} \cdot 30 \mathrm{~d}\right), \quad 15.46 \mathrm{t} /\left(\mathrm{km}^{2} \cdot 30 \mathrm{~d}\right)$ and 11.76 $\mathrm{t} /\left(\mathrm{km}^{2} \cdot 30 \mathrm{~d}\right)$ respectively, which exceeded related foreign limits greatly. The pollution of dustfall in Xi'an city was obvious and serious.

(2) The concentration of $\mathrm{Pb}, \mathrm{Zn}, \mathrm{Cu}, \mathrm{Cr}, \mathrm{Ni}$ and $\mathrm{Cd}$ in dustfall of Xi' an city varied widely with seasons and functional zones. The annual average concentrations was $438.1 \mathrm{mg} / \mathrm{kg}$, $454.9 \mathrm{mg} / \mathrm{kg}, 61.1 \mathrm{mg} / \mathrm{kg}, 149.5 \mathrm{mg} / \mathrm{kg}, 41.4 \mathrm{mg} / \mathrm{kg}$ and 7.8 $\mathrm{mg} / \mathrm{kg}$ orderly, which was $20.5,6.6,2.9,2.4,1.4$ and 83.0 times of the soil background value in Shaanxi province. The pollution of $\mathrm{Pb}, \mathrm{Cr}$, and $\mathrm{Cd}$ was very serious and the pollution level was rather high. $\mathrm{Pb}, \mathrm{Zn}, \mathrm{Cu}, \mathrm{Cr}$ and $\mathrm{Cd}$ were enriched significantly in dustfall and their harmful effect on environment and human health can not be ignored. 
(3) The heavy metal pollution originated from dustfall was serious in $\mathrm{Xi}$ 'an and the annual importations of $\mathrm{Pb}, \mathrm{Zn}, \mathrm{Cu}, \mathrm{Cr}$, $\mathrm{Ni}$ and $\mathrm{Cd}$ of atmospheric deposition were $81.35 \mathrm{mg} /\left(\mathrm{m}^{2} \cdot \mathrm{a}\right)$, $84.47 \mathrm{mg} /\left(\mathrm{m}^{2} \cdot \mathrm{a}\right), 11.35 \mathrm{mg} /\left(\mathrm{m}^{2} \cdot \mathrm{a}\right), 27.76 \mathrm{mg} /\left(\mathrm{m}^{2} \cdot \mathrm{a}\right), 7.69$ $\mathrm{mg} /\left(\mathrm{m}^{2} \cdot \mathrm{a}\right)$ and $1.45 \mathrm{mg} /\left(\mathrm{m}^{2} \cdot \mathrm{a}\right)$ respectively..

\section{ACKNOWLEDGEMENTS}

This study was supported by the National Natural Science Foundation of China (Grant No. 51308050). The authors gratefully acknowledge Nan Jiang and Xuan Li from Environmental Monitoring Station of Xi'an for their enthusiastic help in dustfall sampling.

\section{REFERENCES}

[1] L. Bai and Z. L. Wang, "Anthropogenic influence on rainwater in the Xi'an City, Northwest China: Constraints from sulfur isotope and trace elements analyses," Journal of Geochemical Exploration, vol. 137, pp. 65-72, February 2014.

[2] J. Dallarosa, T. E. Calesso, L. Meira and F. Wiegand, "Study of the chemical elements and polycyclic aromatic hydrocarbons in atmospheric particles of $\mathrm{PM}_{10}$ and $\mathrm{PM}_{2.5}$ in the urban and rural areas of South Brazil," Atmospheric Research, vol. 89, pp. 76-92, July 2008.

[3] Y. J. Yang, Y. S. Wang, T. X. Wen, W. Li, Y. N. Zhao and L. Li, "Elemental composition of $\mathrm{PM}_{2.5}$ and $\mathrm{PM}_{10}$ at Mount Gongga in China during 2006," Atmospheric Research, vol. 93, pp. 801-810, August 2009.

[4] Q. Q. Qiao, B. C. Huang, C. X. Zhang, J. D. A. Piper, Y. P. Pan and Y. Sun, "Assessment of heavy metal contamination of dustfall in northern China from integrated chemical and magnetic investigation," Atmospheric Environment, vol. 74, pp. 182-193, August 2013.

[5] H. W. Vallack and D. E. Shillito, “ Suggested guidelines for deposited ambient dust," Atmospheric Environment, vol. 32, pp. 2737-2744, August 1998.

[6] S. S. Huang, M. Hua, Y. Jin, X. M. Wu, Q. L. Liao, B. W. Zhu and Y. M. Pan, "Concentrations and sources of heavy metal in atmospheric dustfall in the Nanjing city, East China," Earth Science Frontiers, vol. 15, pp. 161-166, September 2008.

[7] H. Xu, F. M. Lin, X. H. Bi, L. Jiao, Y. C. Feng, S. M. Hong and W. G. Liu, "Chemical characteristics of atmospheric dustfall and $\mathrm{PM}_{10}$ in Hangzhou," China Environmental Science, vol. 31, pp. 1-7, January 2011.

[8] R. L. Yu, G. R. Hu, H. L. Qi and F. L. Chen, "Pollution and ecological risk assessment of heavy metals in the dustfall from different functional areas of Quanzhou city," Environmental Chemistry, vol. 29, pp. 1086-1090, November 2010

[9] Z. X. Liu, G. Z. Wang, R. Guo, K. Huang and Y. Zhang, "Characteristics and source analysis of elements in dustfall in Pingdingshan city," Environmental Chemistry, vol. 30, pp. 825-831, April 2011.

[10] Y. Tasdemir, C. Kural, S. S. Cindoruk and N. Vardar, "Assessment of trace element concentrations and their estimated dry deposition fluxes in an urban atmosphere," Atmospheric Research, vol. 81, pp. 17-35, July 2006.

[11] China National Environmental monitoring Center, Peking University and Institute of Applied Ecology,Chinese Academy of Sciences,Shenyang, Background Values of Soil Elements in China, Beijing: China Environmental Science Press, 1990. 